\title{
Preserving the Environment within the ASEAN Skies: Lessons from the European Union Emissions Trading Scheme
}

\section{Ridha Aditya Nugraha}

Air and Space Law Studies, Universitas Prasetiya Mulya, Indonesia. E-mail: ridha.nugraha@pmbs.ac.id

\author{
ARTICLE INFO \\ Keywords: \\ ASEAN Skies; Aviation \\ Emissions; Emissions \\ Trading Scheme; \\ Environment; European \\ Union \\ How to cite: \\ Nugraha, R.A. (2018). \\ Preserving the Environment \\ within the ASEAN Skies: \\ Lessons from the European \\ Union Emissions Trading \\ Scheme. Hasanuddin Law \\ Review, 4(1): 15-29 \\ DOI: \\ 10.20956/halrev.v4i1.1343
}

\begin{abstract}
The United Nations Framework Convention on Climate Change also known as the Kyoto Protocol has set up a framework to reduce carbon emission. The environmental issue is also being addressed at the international aviation sector through the International Civil Aviation Organization's resolutions. As an international organization sui generis, the European Union (EU) has decided to take up a further step with the enactment of the EU Emissions Trading Scheme. The latter has obliged both EU and non-EU airlines to comply with its ambitious goal controlling aviation emissions. However, the legal framework had triggered international objections from legal perspective due to infringement towards the Chicago Convention of 1944 and the international customary law principles. Considering of the nature of the Association of South East Asian Nations (ASEAN) as an international organization without a supranational law order; as well as recent developments in regards to legal framework on emissions, the future of ASEAN skies from an environmental perspective seems uncertain. However, if ASEAN Emissions Trading Scheme shall take place, they should learn from the EU Emissions Trading Scheme past mistakes and the International Civil Aviation Organization resolutions to prevent non-discrimination towards non-ASEAN member states' airlines from happening.
\end{abstract}

Copyright (C) 2018 HALREV. All rights reserved.

\section{Introduction}

Two decades ago, the Kyoto Protocol ${ }^{1}$ was signed to reduce carbon emissions. The high levels of emissions as a result of more than 150 years of industrial activity had arisen many states concerns to act. ${ }^{2}$ The Kyoto Protocol is seen as an important step to reduce

1 United Nations Framework Convention on Climate Change, 10 December 1997. Entered into force on 16 February 2005. Hereby will refer as the Kyoto Protocol.

2 United Nations Climate Change. Kyoto Protocol. Available online from: http://unfccc.int/ kyoto_protocol/items/2830.php. [Accessed March 26, 2018]. 
and stabilize global emissions; more importantly, to become a basis for future international agreement on climate change. ${ }^{3}$ In regards to the aviation sector, realizing the global commitment to reduce carbon emissions, the International Civil Aviation Organization (ICAO) ${ }^{4}$ has been appointed to coordinate technical cooperation to deal with the Kyoto Protocol goals. As a result, at the international stage, ICAO has formulated a carbon calculator to establish a global calculation method as a standard.

As of today, emissions from civil aviation only account for $2 \%$ of global carbon emissions. ${ }^{5}$ However, within the next decades, the aviation sector will have a more significant contribution towards carbon emissions production considering the projected airline market growth. ${ }^{6}$ For instance, back in 2013, the ICAO projected that the number of aircraft serving commercial flights would triple by 2040.7

In response to the Kyoto Protocol and ICAO efforts to this projected forecast, the European Union (EU) as an international organization with supranational law order has implemented the European Union Emissions Trading Scheme (EU ETS) since 2005. As a legal basis within the regional jurisdiction, the EU has enacted Directive 2008/101/EC, as an amendment of Directive 2003/87/EC scope to the aviation sector which has been in force since 1 January 2012. In this context, the EU ETS shall refer only to the aviation sector. Both EU Directives are meant to reduce carbon emissions. ${ }^{8}$

The applicability of the EU ETS used to mean an aircraft would be charged for its emissions for the entire flight, including over the high seas and outside the EU territory, irrespective of their origin or destination as long it lands or departs from an EU airport. ${ }^{9}$ In other words, nationality of the aircraft does not play a role within this scheme. Due to the opposition of several non-EU states and airlines shortly after the introduction of the EU ETS, the EU decided only to apply the scheme to intra-EU flights (stop the clock decision). Furthermore, this scheme leads to a scenario for non-EU carriers ${ }^{10}$ either to buy carbon allowances or to reduce its market share or flights to and from the EU; which

Ibid.

4 The International Civil Aviation Organization (ICAO) is a specialized United Nations agency established on 14 April 1947. Headquartered in Montreal, Canada, with 192-member states per-November 2017. The organization is established with aim to manage the administration and governance of the Convention on International Civil Aviation - also known as the Chicago Convention of 1944. See International Civil Aviation Organization. About ICAO. Available online from: https://www.icao.int/abouticao/Pages/default.aspx. [Accessed March 25, 2018].

5 Uwe M. Erling. (2017). "International Aviation Emissions Under International Civil Aviation Organization's Global Market Based Measure: Ready for Offsetting?". Air \& Space Law, 42(1): 1.

6 Ibid.

7 International Civil Aviation Organization. (2013). ICAO Environmental Report 2013: Aviation and Climate Change, p. 21.

8 Directive is a legislative act that sets out a goal that all EU member states must achieve. It is up to each member states to devise their own laws on how to reach these goals. See European Union. Regulations, Directives and other acts. Available online from: https://europa.eu/european-union/eu-law/legalacts_en. [Accessed March 25, 2018].

9 European Union. Directive 2008/101/EC, arts. 3(d) and 3(r).

10 The term "EU carrier" or "Community air carrier" refers to Article 4(f) EU Regulation No. 1008/2008 on common rules for the operation of air services in the Community. The article mentions, "[A]n undertaking shall be granted an operating licence by the competent licensing authority of a Member State provided that: (f) Member States and/or nationals of Member States own more than $50 \%$ of the undertaking and effectively control it, whether directly or indirectly through one or more intermediate undertakings, except as provided for in an agreement with a third country to which the Community is a party". In other words, an airline shall not be deemed as an EU carrier or Community air carrier if EU member states or its nationals hold less than $50 \%$ of the total shares. 
under a projection back in 2012 stated it will increase fare up to 40 Euro per passenger and cost 17.7 billion to comply with the EU ETS until 2020.11

In terms of sanctions, any carrier is subject to a fine of 100 Euro per ton $\mathrm{CO}_{2}$ emissions and also under an obligation to return the exceeding emission as mandated within the EU ETS.12 When this fine is being ignored, the relevant (administering) member state could take more severe action by addressing the EU Commissions to ban the airline from operating within the EU. Regarding the member state(s) relationship with the third country, this situation means going far beyond the bilateral air service agreements conducted between them.

From one perspective, the EU ETS could become a solution. The method is considered ambitious concerning its application to both EU and non-EU carriers, thus disregarding nationality. The total emissions from the aviation sector between 2004 and 2006 become the reference point; wherein 2013-2020 aviation emissions will be capped at $95 \%$ of that point. On the other hand, this method used to gain objections from non-EU carriers with various reasons, one of them is legality - namely questioning whether the EU, as an international organization sui generis, is entitled to charge non-EU carriers for emissions generated from the entire flight, including over the high seas and outside the EU territory.

This research shall discuss the original version of EU ETS mainly from the legal perspective, namely the United Nations Framework Convention on Climate Change (UNFCCC) or Kyoto Protocol and the Chicago Convention of $1944^{13}$ as the magna carta of the international aviation sector. Legality of the scheme shall be tested.

Finally, the Association of South East Asian Nations (ASEAN) could learn a lot from EU ETS mistakes if such kind of ASEAN ETS would be set up in the future. In this article, EU ETS shall refer to the original version - before "stop the clock decision" was made.

\section{Legal Challenges Behind the European Union Emissions Trading Scheme}

In order to provide further legal analysis of the EU ETS, two worldwide legal frameworks, which are the UNFCCC or the Kyoto Protocol and the Chicago Convention, will be taken into account. The former is important to be analyzed considering it has become the world guideline to reduce carbon emissions; while the Chicago Convention as the last guardian of the aviation sector will test whether the EU ETS provisions are inline with the magna carta of international civil aviation.

\subsection{The United Nations Framework Convention on Climate Change}

Contracting states are required to provide the report on the development of their greenhouse gases, including aviation emissions. ${ }^{14}$ This legal framework raises an issue towards international aviation emissions because of the principle of territoriality; which means the report must be delivered by the country of origin. Thus, a challenge to be applied to the aviation sector, considering $70 \%$ of the earth is covered by oceans or high

\footnotetext{
11 Brian F. Havel and John Q. Mulligan. (2012). “The Triumph of Politics: Reflections on the Judgment of the Court of Justice of the European Union Validating the Inclusion of Non-EU Airlines in the Emissions Trading Scheme". Air \& Space Law, 37(1): 4.

12 European Union, op.cit., art. 16(3).

13 Convention on the International Civil Aviation, 7 December 1944.

14 The Kyoto Protocol, arts. 4 and 12.
} 
seas, and it is still unclear to which state the emissions shall be attributed for cross-border or international flights. ${ }^{15}$

As today, ICAO is recognized as the appropriate organization to deal with international flights emissions. This could be seen by the mutual cooperation between ICAO and UNFCCC, where ICAO regularly reports its progress to the Subsidiary Body for Scientific and Technological Advice of the UNFCCC; and conversely, the latter becomes an observer in ICAO's Committee on Aviation Environmental Protection. ${ }^{16}$

Speaking of international flights, so far, the emissions are reported as Memo Items stipulated within Annex 1 of the Kyoto Protocol and not being a subject for the reduction target of the Protocol. ${ }^{17}$ Almost three decades later where international aviation market has grown significantly, from fleet expansions until the establishment of airline alliances, a gap exists for combatting global warming. One thing for sure is only domestic aviation emissions are counted as national emissions of a country. ${ }^{18}$

Living within the globalization era where state border becomes borderless, also in the triumph of air transport liberalization in many places of the world, no doubt movement is inevitable. The liberalization of air transport itself has been conducted during the last three decades. ${ }^{19}$ Between 1997-2007, the number of annual passengers has grown from 1.457 billion to 2.128 billion per year ( $46 \%$ growth). ${ }^{20}$ For the past five years, air travel growth has averaged $6.2 \% .{ }^{21}$ There is a need for 41,000 new aircraft deliveries over the next two decades to answer the increasing demand for air transportation. ${ }^{22}$

International flights are mushrooming with the enactment of many open skies policy in the absence of strong commitment to reducing aviation emissions. The gap within international flights to count aviation emissions presents a 'reasonable' entry point for the EU to implement the EU ETS.

\subsection{The Chicago Convention of 1944}

Realizing the magna carta of air law as one of the most successful international treaties with $192^{23}$ signatories in 2018, not surprisingly every EU member states have become contracting states to this convention. When it comes to the EU, they are 'bound' by the Chicago Convention despite not being a signatory. ${ }^{24}$ The fact that EU member states pursue their own bilateral air service agreements with non-EU countries, orchestrated

5 Uwe M. Erling, op.cit., 2.

Ibid., 3.

Ibid., 2.

18 Steven Truxal. (2011). “The ICAO Assembly Resolutions on International Aviation and Climate Change: An Historic Agreement, a Breakthrough Deal, and the Cancun Effect". Air E Space Law, 36(3): 219.

19 International Civil Aviation Organization. (2016). Working Paper A39-WP/189, p. 2.

20 International Civil Aviation Organization. (2007). Outlook for Air Transport to the Year 2025.

21 Boeing. (2017). Current Market Outlook 2017-2036, 7.

22 Ibid., 20.

23 International Civil Aviation Organization. The History of ICAO and the Chicago Convention. Available online from: https://www.icao.int/about-icao/History/Pages/default.aspx. [Accessed January 4, 2018].

24 Article 1 of the Chicago Convention mentions only states could become the signatories. As the implication, EU as an international organization sui generis could not sign the convention. However, with the fact that all EU member states are the Chicago Convention signatories, a conclusion could be drawn that the convention rules and provisions are alive within EU. 
by the European Commissions guidelines ${ }^{25}$, shows that there is no transfer of powers from each member states to the EU. ${ }^{26}$

In realms of the functional succession legal theory, the EU's stance towards the Chicago Convention is different than what the Court of Justice of the European Union (CJEU) has previously accepted in the International Fruit Company Case $27 .{ }^{28}$ The case has strengthened the premise that EU is not deemed automatically as the successor of its member states in the international aviation sector.

As a consequence, it leads us into the debate whether the EU has exclusive sovereignty over its airspace..$^{29}$ The first two articles of the Chicago Convention clearly mentioned that each state has complete sovereignty over its airspace, but not over the high seas more over other state(s) airspace. The EU ETS legality through Directive 2008/101/EC used to be at stake when international flights emissions calculation, to or departing from the EU, were also counted for passages outside the member states' airspace. For example, a flight from San Francisco to Amsterdam which spent most of its time in United States, Canada, and the high seas airspace according to EU ETS shall be calculated for the whole flight - not only when entering the EU airspace. ${ }^{30}$ This scenario was definitely an infringement towards other states sovereignty and also customary international law principles.

On the contrary, the CJEU has expressed a different judgement. As legal scholars, Brian F. Havel and John Q. Mulligan, conclude it,

"The Advocate General and the CJEU examine that complaint and reject it, determining that Directive 2008/101 does not regulate extraterritorial activity because it takes account of the extraterritorial activity only to an extent justified by a sufficient territorial link and does not infringe on any State's sovereignty over its airspace." 31

The aircraft 'free choice' to depart from or land at EU points confirms that they are fully aware of EU ETS and decides to obey and comply with its provisions, including the controversial calculation method. Through CJEU Judgement in Air Transport Association of America and Others v. Secretary of State for Energy and Climate Change 32, the physical presence of aircraft within the EU territory has insisted them to become a subject towards

25 See Regulation (EC) No. 847/2004 on the negotiation and implementation of air service agreements between Member States and third countries. Member states do retain the authority to negotiate and amend their bilateral agreements as long they are in line with the regulation.

26 Brian F. Havel and John Q. Mulligan, op.cit., 14.

27 Court of Justice of the European Union. (1972). Joined Cases 21-24/72. International Fruit Company NV and Others v. Produktschap voor Groenten en Fruit.

28 At that time, the CJEU ruled that the European Economic Community (EEC), having assumed from its member states their duties in the jurisdictional area governed by the General Agreement on Tariffs and Trade of 1947 (GATT), was bound by GATT terms even though never becoming a contracting party. See ibid.

29 Brian F. Havel and John Q. Mulligan, op.cit., 23-33.

30 Article 15 of the Chicago Convention regulates Route Air Navigation Service (RANS) Charges. When it comes to international flights, all aircraft are subject to RANS Charges noticing the article mentions this scheme while also acknowledging each state sovereignty. For navigation services held above the high seas which are not within any state sovereignty, ICAO appoints several states to perform such functions. However, the magna carta does not mention any environmental issue, or more specifically, environment charges. This situation means, at some point, sovereignty prevents environment charges conducted by another jurisdiction.

31 Brian F. Havel and John Q. Mulligan, op.cit., 17.

32 Court of Justice of the European Union. (2011). Case C-366/10. Air Transport Association of America and Others v. Secretary of State for Energy and Climate Change. 
the EU jurisdiction, including the applicability of the EU ETS. ${ }^{33}$ In other words, as long the aircraft was flying over the EU airspace or high seas without landing at any member state's airport, then the EU ETS will not apply to them. Furthermore, the EU Advocate General's opinion must be criticized when she suggested the member states would be obligated to withdraw from the Chicago Convention should the EU ETS violate the magna carta - not a reliable framework for sustaining international aviation law. ${ }^{34}$

Aviation emissions allowance could not be regarded as tax or charge as stipulated in Article 15 of the Chicago Convention considering its market-dependent status. ${ }^{35}$ No fixed amount could be calculated in advance, which could be 'dangerous' for aviation business and airlines forecasting their market. With the scheme, 15\% of the aviation allowance is auctioned based solely on market price through supply and demand mechanism; all airlines seemingly open a Pandora's box when operating the EU routes.

Noticing the EU ETS as an iceberg, Article $84^{36}$ of the Chicago Convention provides a dispute settlement procedure which could become a solution. There is a firm ground for non-EU member states to address this issue to ICAO; which is considered as theoretically possible. ${ }^{37}$ Furthermore, as a more extreme scenario, any third state(s) could bring this issue to the International Court of Justice with the basis of an infringement of the customary international law principle, and not the illegality of the EU ETS, as codified by the Vienna Convention on the Law of Treaties of 196938.39

Finally, the legal foundation for the original version of EU ETS was made on thin ice because there was tendency the regional jurisdiction manipulated international law for achieving the environmental goals, thus disrespecting the fundamental value of the EU which is the rule of law. ${ }^{40}$ International law considerations must be taken into account when fostering environmental policies which affect the operation of international air services - including in the EU to avoid infringing the rights non-EU carrier. ${ }^{41}$

\section{Non-EU Airlines' Efforts in Search of Justice}

Prior to the enactment of EU ETS in 2012, four Chinese airlines with China's Air Transport Association (CATA) support planned to sue the EU ETS; with consideration,

33 Ibid., para. 125.

34 Brian F. Havel and John Q. Mulligan, op.cit., 13.

35 Court of Justice of the European Union, op.cit., paras. 143, 214-215. Market-dependent status means the valuation of aviation emissions allowance depends on the current situation which probably changes from time to time. The unpredictable situation is not favourable for airlines.

36 If any disagreement between two or more contracting States relating to the interpretation or application of this Convention and its Annexes cannot be settled by negotiation, it shall, on the application of any State concerned in the disagreement, be decided by the Council. No member of the Council shall vote in the consideration by the Council of any dispute to which it is a party. Any controlling State may, subject to Article 85, appeal from the decision of the Council to an ad hoc arbitral tribunal agreed upon with the other parties to the dispute or to the Permanent Court of International Justice. Any such appeal shall be notified to the Council within sixty days of receipt of notification of the decision of the Council.

37 Pietro Manzini and Anna Masutti. (2012). "The Application of the EU ETS System to the Aviation Sector: From Legal Disputes to International Retaliations?". Air \& Space Law, 37(4/5): 312-313.

38 United Nations. Vienna Convention on the Law of Treaties, 23 May 1969. Entered into force on 27 January 1980. See Article 53.

39 Pietro Manzini and Anna Masutti, op.cit., 314, 323.

40 Pablo Mendes de Leon. (2012). "Enforcement of the EU ETS: The EU's Convulsive Efforts to Export its Environmental Values". Air \& Space Law, 37(4/5): 287-288.

41 Ibid. 
it would cost Chinese carriers 123.6 million US Dollar annually to follow the EU ETS. ${ }^{42}$ India has also taken the same move by stressing its commitment to Kyoto Protocol to reduce aviation emissions and not to the EU ETS. Later on, in May 2013 the European Commission had mentioned a fine totalling 2.4 million Euro for two Indian and eight Chinese airlines due not providing their aviation emissions data nor paying the bills. ${ }^{43}$

Moscow also threatened to join the 'trade war' by raising transit charges through its Siberian airspace. ${ }^{44}$ The German flag carrier, Lufthansa, had difficulties in obtaining permission to operate its Shanghai route on A380 whereas China had deferred or cancelled its Airbus aircraft purchase..$^{45}$ Interesting to notice some non-EU airlines had submitted aviation emissions data without prejudicing their rights under international law, which implies their action should not be deemed as an acceptance of EU ETS regime. 46 Those responses, and also wide spreading in other countries such as the United States which forecasted will burden the industry for millions of Euro, ${ }^{47}$ have shown that once the EU ETS had terrified the global aviation market. In general, some non-EU carriers which possessed a significant market share to and from the EU rejected the EU ETS.

It could be postulated the EU ETS was at odds with the purpose of airline liberalization and open skies arrangements which both promote freedom of movements to boost the economy. Private aircraft operators are also subject to EU ETS even though they produce less than $0.04 \%$ of carbon emissions. 48

When it comes to airline alliances that engage in code-sharing practice serving intra-EU or intercontinental flight to the EU, the non-EU airlines potentially become the most harmed parties. In the context being the contracting carrier, logically EU ETS is also applicable to any ticket they sell. The question shall be whether the non-EU airlines must pay for emission allowances even though they are not the operating carrier. More specifically, if the EU airlines as the operating carrier have fulfilled their duties on emission allowances according to EU ETS, does this exempt the remaining contracting carriers for not being double charged?

The debate does not end here. Within the last years, there has been doubt whether the money coming generated under EU ETS will end up at the right place; ${ }^{49}$ or being used for other purposes such as funding the Air Navigation Service Provider (ANSP) or even state-aiding Alitalia to pay its debts. Failure to safeguard the funds shall trigger the discouragement of more airlines to participate in the EU ETS and even to sue this scheme at international level. More transparency is needed.

42 China Aviation Daily. (2011). Four Chinese Carriers Will File Lawsuit over EU ETS. Available online from: http://www.chinaaviationdaily.com/news/17/17078.html. [Accessed January 4, 2018].

43 Livemint. (2013). EU Says It Hasn't Sent Penalty Notifications to Air India, Jet. Available online from: http://wwww.livemint.com/Politics/ZKtKeEe01IaPpzpsp8FnGI/EU-says-it-hasnt-yet-sent-penalty-notificationsto-Air-Indi.html. [Accessed January 4, 2018].

44 The Moscow Times. (2012). European Airlines Denied Overflight. Available online from: https://themoscowtimes.com/articles/european-airlines-denied-overflight-15383. [Accessed January 4, 2018].

45 Pablo Mendes de Leon, op.cit., 293.

46 Ibid., 300.

47 Bloomberg New Energy Finance. (2011). Including Aviation in the EU ETS - The Burning Question. Available online from: https://about.bnef.com/blog/including-aviation-in-the-eu-ets-the-burning-question/. [Accessed January 4, 2018].

48 Ulrich Steppler and Angela Klingmüller. (2009). "EU Emissions Trading Scheme and Aviaton: Quo Vadis?". Air \& Space Law, 34(4/5): 259.

49 Ibid., 260. 
In fact, the aviation industry has already answered the environment issue addressed by EU ETS in parallel. As today, aircraft manufacturers have competed tightly to increase its product efficiency. Each year we see Airbus and Boeing making announcements on their innovations in the name of environmentally friendly, such as A320 or B737 new series. In the realms of global politics, instability encourages fuel price fluctuations, as well as tighter competition between airlines either full-service or low-fare in all parts of the world, choosing the most efficient aircraft for its fleet is the answer. Thus, airlines are investing in new aircraft which save more fuels to reduce aviation emissions. The current market-driven situation has implicitly promoted environmental protection.

Any non-EU airlines whose rights are being injured by EU ETS could address the issue to ICAO through their government. The dispute settlement procedure as stipulated in Article 84 of the Chicago Convention shall end up with negotiation or consultation between the relevant parties. ${ }^{50}$ Failure within the process would trigger the arbitration. Until now, there were only very few cases which ended up with arbitral tribunal, showing a high success rate of negotiation or consultation. ${ }^{51}$ However, learning from the "stop the clock decision", the EU ETS dispute with third countries seems most likely to be resolved at political level instead of a legal forum.

\section{What the Association of South East Asian Nations Could Learn}

\subsection{Recent Developments to Preserve the Environment}

In 2010, the ICAO had adopted Resolution A37-19 which put commitments on states to preserve the environment through ICAO to achieve an aspirational global fuel efficiency improvement rate of $2 \%$ per annum from 2021 to 2050.52 Some states such as Argentina, China, and Venezuela had expressed their objections by saying the Resolution leaves a gap that forgets the interest of developing countries..$^{53}$

Back to the year of 1972, the Stockholm Declaration on the Human Environment mentioned,

"The environmental policies of all States should enhance and not adversely affect the present and future development potential of developing countries, nor should they hamper the attainment of better living conditions for all..."54

Those above have implied that the original version of EU ETS would not suit with the current norm and was slightly too ambitious by harming other non-EU states' airlines, especially from the developing countries. 55

50 See footnote no. 36 for the full provision.

51 John Balfour. "Arbitration in Aviation: The Ultimate Remedy?" on The International Bureau of the Permanent Court of Arbitration (ed.). (2002). Arbitration in Air, Space and Telecommunications Law. Den Haag: Kluwer Law International, pp. 89-92.

52 International Civil Aviation Organization. (2010). Assembly Resolution A37-19, para. 4.

53 Michel Adam. (2011). "ICAO Assembly's Resolution on Climate Change: A 'Historic' Agreement?". Air E Space Law, 36(1): 24-25.

54 United Nations Conference on the Human Environment, June 1972. Principle 11.

55 There is no established convention for the designation of "developed" and "developing" countries or areas in the United Nations system. In common practice, Japan in Asia, Canada and the United States in northern America, Australia and New Zealand in Oceania and Europe are considered "developed" regions or areas. In international trade statistics, the Southern African Customs Union is also treated as developed region and Israel as a developed country; countries emerging from the former Yugoslavia are treated as developing countries; and countries of Eastern Europe and the former USSR countries in Europe are not included under either developed or developing regions. Indonesia is categorized as 
There are some scenarios for non-EU airlines to avoid EU ETS, such as not doing transit in EU airports. What does it mean if the carrier must travel further thus produces more emissions? The aircraft could succeed avoiding the emissions allowance, but in fact, pollutes more. It is feared that both original and current version of EU ETS could become a counterproductive measure for combatting global emissions based on finding the best route.

Potentially, retaliation from another state(s) or regional initiative(s) will happen when EU ETS burdens more non-EU airlines in the future to ensure less competition for EU airlines. This could be in the form of national laws enacted which forbid its national carrier(s) to comply with EU ETS; 56 or in a more prominent scale, with the establishment of a similar scheme like EU ETS under national jurisdiction or even international organization such as the ASEAN. Without a doubt, this is dangerous for international aviation; justice through respecting other states sovereignty and also customary international law principles must be restored to prevent any retaliation from happening.

As the recent development at the global stage, ICAO has enacted Resolution A39-357 which aims to provide a global market-based measure scheme related to environmental protection. The scheme is implemented in the form of the Carbon Offsetting and Reduction Scheme for International Aviation (CORSIA) to address any annual increase on emissions from international civil aviation flights after 2020.58 CORSIA shall apply to international routes between the state's participants; 59 exempting the non-participants to avoid infringing other states sovereignty which is deemed as a customary international law principle.

One firm ground from CORSIA is that emissions generated from mechanism established under the UNFCCC and the Paris Agreement are eligible for use. ${ }^{60}$ This situation strengthens the premise that international aviation emissions should be accounted for only once. As of August 2017, 72 states representing 87.7\% of international aviation activity, intend to participate CORSIA voluntarily. ${ }^{61}$

\subsection{ASEAN Legal Framework Pertaining to Aviation Emissions}

ASEAN has actively promoted clean and green environment issue within the last decade. The ASEAN Declaration on Environmental Sustainability of 200762 could be deemed as the main entry point. To implement the declaration, the ASEAN Socio-

developing country. See the Organization for Economic Co-operation and Development. (2006). Developed, Developing Countries. Available online from: http://stats.oecd.org/glossary/detail.asp?ID=6326. [Accessed March 29, 2018].

56 The United States enacted the European Union Emissions Trading Scheme Prohibition Act of 2011 on 27 November 2012 which prohibited any civil aircraft of the US from participating in the EU ETS.

57 International Civil Aviation Organization. (2016). Assembly Resolution A39-3.

58 Ibid., para. 5.

59 Ibid., para. 10. There are three phases of implementation, i.) pilot phase (2021-2023); ii.) first phase (20242026); and iii.) second phase (2027-2035). The first two phases are voluntary, while the last one is mandatory except for the exempted ones which are categorized based on aviation-related criteria and socio-economic indicator. See also para. 9 for further explanation. Furthermore, how CORSIA is implemented among the member states shall depend on each national legal system.

$60 \quad$ Ibid., para. 21.

61 International Civil Aviation Organization. (2017). Carbon Offsetting and Reduction Scheme for International Aviation (CORSIA). Available online from: https://www.icao.int/environmental-protection/Pages/marketbased-measures.aspx. [Accessed January 4, 2018].

62 Association of the South East Asian Nations Declaration on Environmental Sustainability, Singapore, 20 November 2007. 
Cultural Community Blueprint 2009-201563 had been enacted whereas addressing global environmental issues, including emissions, was one of the primary programs. Currently, the Community Blueprint has been renewed for the period 2016-2025 which also stresses emissions issues. ${ }^{64}$

Unfortunately, there is no specific provision on preserving the environment following to aviation emissions in ASEAN. This situation means opening the door to the ICAO CORSIA; taking into account as of 23 August 2017, four ASEAN countries, namely Indonesia, Thailand, Malaysia, and Singapore which play a significant role within the region due to their massive airspace in total have declared their intention to voluntarily participate CORSIA. Unlike the Bratislava Declaration 65 which obliges every EU member states to participate CORSIA, there is no such declaration or legal framework that obligates the ASEAN member states taking the similar path.

\subsection{The Prospect for Establishing an ASEAN Aviation Emissions Trading Scheme}

First of all, ASEAN has evolved from a regional initiative into an international organization with the signing of ASEAN Charter on 15 December 2008. Established based on non-interference principle, this leads the absence of supremacy of ASEAN law. As a consequence, this situation raises an issue how to implement the enacted ASEAN legal framework on the environment in their respective domestic laws.

One should also note the concept of the single aviation market in ASEAN, or also known as the ASEAN Open Skies ${ }^{66}$, is far different from the EU's. The $8^{\text {th }}$ and $9^{\text {th }}$ Freedom of the Air or cabotage are still prohibited in ASEAN; now only up to the $5^{\text {th }}$ Freedom of the Air is allowed for the member states' airlines. ${ }^{67}$ As a comparison, there is no restriction for cabotage in the EU. While for non-ASEAN member states, how far the Freedom of the Air is being granted depends on the existing bilateral agreements with each ASEAN member states; there is no rigid standard or pattern. This situation plays a role in limiting the number of flights which connected ASEAN airports considering only national carrier could serve domestic routes.

Furthermore, no definition of "ASEAN carrier" has been set up. The maximum foreign ownership shares allowed varies within each ASEAN member states, from $49 \%$ in

63 Association of the South East Asian Nations. (2009). Roadmap for an ASEAN Community 2009-2015.

64 Association of the South East Asian Nations. (2016). ASEAN Socio-Cultural Community Blueprint 2025, section C.3 points iv-vii.

65 Declaration of Directors General of Civil Aviation of EU Member States and the Other Member States of the European Civil Aviation Conference: Adhering to the Global Market-Based Measure (GMBM) Scheme from the Start, Bratislava, 3 September 2016.

66 The ASEAN Open Skies Policy came into effect on 1 January 2015. The policy, which is also known as the ASEAN Single Aviation Market, is intended to increase regional and domestic connectivity, integrate production networks and enhance regional trade by allowing airlines from ASEAN member states to fly freely throughout the region via the liberalization of air services under a single and unfied air transportation market.

67 The $5^{\text {th }}$ Freedom of the Air: the right or privilege, in respect of scheduled international air services, granted by one State to another State to put down and to take on, in the territory of the first State, traffic coming from or destined to a third State.

The $8^{\text {th }}$ Freedom of the Air: the right or privilege, in respect of scheduled international air services, of transporting cabotage traffic between two points in the territory of the granting State on a service which originates or terminates in the home country of the foreign carrier or outside the territory of the granting State.

The 9th Freedom of the Air: the right or privilege of transporting cabotage traffic of the granting State on a service performed entirely within the territory of the granting State. 
Indonesia ${ }^{68}$ and Thailand ${ }^{69}$ until $100 \%$ in Cambodia ${ }^{70}$. There is a chance that a foreign company owns the shares of an Indonesian carrier through an intermediary company which ends up with (holding) corporate control as appeared in Indonesia AirAsia business model. ${ }^{71}$ As one of the consequences, it slows the progress on defining "intraASEAN flights". This step is essential to set up a legal ground if ASEAN decides to enact their own rule on aviation emissions.

If ASEAN decides to implement its own emissions trading scheme, the main legal question shall be whether the emissions calculation should start when an aircraft departs from a member state's airport en route to the other member state's; or at the moment an aircraft enters the ASEAN skies disregard its nationality. The scenario could be expanded as whether just flying above the ASEAN skies without landing at any member state's airport could establish a legal ground to collect emission allowance. For example, a direct flight from Hong Kong to Darwin will spend most of the time within ASEAN skies; which also means significantly polluting the air.

Considering of ASEAN strategic location based on the Hong Kong-Darwin flight example, it is very logical if ASEAN establishes such kind of ASEAN Emissions Trading Scheme (ASEAN ETS). However, the current ASEAN legal framework has not set up a fundamental for such emissions trading scheme, especially pertaining to the aviation sector. Furthermore, with the absence of an ASEAN aviation agency or commission, another question arises whom will be held responsible for managing and regulating aviation environmental issue since no relevant institution has been set up.

The absence of ASEAN Court of Justice and ASEAN law, in this context hard law, also play an important role if ASEAN would like to implement its own emissions trading scheme. Soft laws could be a solution answering this situation. ${ }^{72}$ There must be a forum to settle any arising dispute in regards to aviation environmental issue between the ASEAN member states; between ASEAN and the member state(s); or between ASEAN and individual(s) or corporate(s) (i.e. both member and non-member states' airline). Relying on any member state's forum without the rule of law ${ }^{73}$ shall mean a disaster for the continuation of the ASEAN ETS. It appears that establishing a focal point in each member states for ensuring such implementation should also be considered noticing ASEAN emphasises non-interference in other states' domestic affairs.

68 Indonesia. Presidential Regulation No. 36 Year 2010 regarding List of Business which are Closed and Conditionally Open for Foreign Investment.

69 Thailand. Act Year 1954 regarding Air Navigation.

70 CAPA - Centre for Aviation. (2014). Cambodian Aviation's Surge in Airline Starts-Ups as Chinese Traffic Drives Rapid Growth. Available online from: https://centreforaviation.com/insights/analysis/cambodiasaviation-surge-in-airline-start-ups-as-chinese-traffic-drives-rapid-growth-179184. [Accessed January 3, 2018].

71 Ridha Aditya Nugraha. (2015). "AirAsia: Flying Cabotage Under Cloak in Indonesia and ASEAN". Jurnal Hukum \& Pembangunan. 45(2): 163-180.

72 Speaking of transboundary haze pollution as one of the major problems between ASEAN member states, the ASEAN Agreement on Transboundary Haze Pollution has been set up. Some other haze-related soft law and policy are also being set up. They are set up noticing the so-called 'ASEAN Way' which emphasises non-interference in other states' domestic affairs. This scheme shows the significant role of soft laws in ASEAN.

73 The rule of law is a legal principle that supports the equality of citizens before the law and prevents any arbitrary use of power by government. The expression 'certainty' in this context means that a law must be accessible, possible intelligible, clear and predictable. See Tom Bingham. (2010). The Rule of Law. London: Penguin Group, p. 37. See also Britannica Academic. Rule of law. Available online from: http://academic.eb.com/levels/collegiate/article/rule-oflaw/603027;jsessionid $=$ BC834083553FE6758AC275303E188F7F. [Accessed March 29, 2018]. 
Not to be forgotten, ASEAN also needs to solve a homework whether the income generated shall be deemed as aviation charge or tax. More transparency is required to build trust that any revenue generated from this sector will end up at the right place, namely only to preserve the environment.

Based on the situation as mentioned above, also in the realms of CORSIA whereas four ASEAN member states have confirmed their participation, it seems not favourable to set up an ASEAN ETS pertaining to the aviation sector. However, if such drafting of ASEAN ETS still takes place, the past EU ETS fatal mistake which calculated the whole flight, not only when entering the EU airspace, must not be repeated. Compliance with the Kyoto Protocol and CORSIA should be held at the utmost care to prevent overlapping and contradicting policies. Once ASEAN ETS infringes other states sovereignty and also customary international law principles, indeed this will bring the idea to an end.

\section{Conclusion}

The world is struggling to preserve the sustainable environment as well as combatting global warming through the Kyoto Protocol. Appreciation must be addressed to ICAO with the initiative by setting up carbon calculator and emissions goal despite the aviation sector only accounting for $2 \%$ of the global carbon emissions.

The controversy began when EU ETS was enacted to regulate aviation emissions. Not to disagree with the ambitious goal, however the original scheme had harmed some legal principles, namely the Chicago Convention of 1944 as the magna carta of the international aviation sector and customary international law as regulated within the Vienna Convention on the Law of Treaties of 1969 - namely sovereignty, which affected the nonEU airlines flying to or from the EU. Still, from the legal point of view, the debates on EU ETS had shown the lack of understanding of the international air law and policy on the part of the EU, in particular, the CJEU. ${ }^{74}$

The growth of traffic following to ASEAN Open Skies potentially threatening the environment considering there is no specific provision on preserving the environment following to aviation emissions in the region. Such threat becomes more tangible with the nature of ASEAN as an international organization without a supranational law order. The non-interference principle which lives among the member states raises an issue how to implement the enacted ASEAN legal framework on the environment in their respective domestic laws. This situation leads to the scheme of utilizing soft laws for mitigating aviation emission. At the moment, there is no discussion to regulate aviation emissions like EU ETS.

Noticing the situation in ASEAN and EU, as one of the solutions, both the Kyoto Protocol and ICAO must be encouraged. While the former deals with domestic aviation emissions, the latter deals at the international stage guided by its carbon calculator method as well as ICAO Resolution A39-3 or CORSIA. Indeed, separation of functions but working together.

Finally, the topic of environmental protection in the aviation sector is not an issue of competition, but an issue of a global cooperation whereas each party should agree on the settings from the beginning. The establishment of such kind of ASEAN ETS could be even more harmful to the environment without such cooperation. Despite the recent developments in ASEAN as mentioned above, it must not be forgotten that aviation

74 Pablo Mendes de Leon, op.cit., 305. 
sector nature is unique. Everything could happen, including the implementation of ASEAN ETS even though there is no proper institution and legal framework yet; and also, in the realms of CORSIA. In other words, the future is still uncertain.

\section{Acknowledgement}

The author wishes to thank the German Aviation Research Society funding support for this research. Last but not least, special thanks go to Prof. Frank Fichert (Hochschule Worms), Dr. Tolga Ülkü (Berlin School of Economics and Law), and Wolfgang Grimme (Deutsches Zentrum für Luft- und Raumfahrt / DLR; or German Aerospace Center) for their comments upon the original article as presented at the 14th German Aviation Research Society-Airneth Junior Researcher Workshop on 3-4 July 2017 in Amsterdam, the Netherlands.

\section{References}

Adam, M. (2011). ICAO Assembly's Resolution on Climate Change: A 'Historic' Agreement?. Air E Space Law, 36(1), 24-25.

Association of the South East Asian Nations Declaration on Environmental Sustainability, Singapore, 20 November 2007.

Association of the South East Asian Nations. (2009). Roadmap for an ASEAN Community 2009-2015.

Association of the South East Asian Nations. (2016). ASEAN Socio-Cultural Community Blueprint 2025.

Bingham, T. (2010). The Rule of Law. London: Penguin Group.

Bloomberg New Energy Finance. (2011). Including Aviation in the EU ETS - The Burning Question. Available online from: https://about.bnef.com/blog/including-aviation-inthe-eu-ets-the-burning-question/. [Accessed January 4, 2018].

Boeing. (2017). Current Market Outlook 2017-2036.

Britannica Academic. Rule of law. Available online from: http://academic.eb.com/levels/collegiate/article/rule-oflaw/603027;jsessionid=BC834083553FE6758AC275303E188F7F. [Accessed March 29, 2018].

CAPA - Centre for Aviation. (2014). Cambodian Aviation's Surge in Airline Starts-Ups as Chinese Traffic Drives Rapid Growth. Available online from: https://centreforaviation.com/insights/analysis/cambodias-aviation-surge-in-airline-startups-as-chinese-traffic-drives-rapid-growth-179184. [Accessed January 3, 2018].

China Aviation Daily. (2011). Four Chinese Carriers Will File Lawsuit over EU ETS. Available online from: http://www.chinaaviationdaily.com/news/17/17078.html. [Accessed January 4, 2018].

Convention on the International Civil Aviation, 7 December 1944.

Court of Justice of the European Union. (1972). Joined Cases 21-24/72. International Fruit Company NV and Others v. Produktschap voor Groenten en Fruit. 
Court of Justice of the European Union. (2011). Case C-366/10. Air Transport Association of America and Others $v$. Secretary of State for Energy and Climate Change.

Declaration of Directors General of Civil Aviation of EU Member States and the Other Member States of the European Civil Aviation Conference: Adhering to the Global Market-Based Measure (GMBM) Scheme from the Start, Bratislava, 3 September 2016.

de Leon, P.M. (2012). Enforcement of the EU ETS: The EU's Convulsive Efforts to Export its Environmental Values. Air \& Space Law, 37(4/5), 287-288.

Erling, U.M. (2017). International Aviation Emissions Under International Civil Aviation Organization's Global Market Based Measure: Ready for Offsetting?. Air E Space Law, 42(1), 1.

European Union. Directive 2008/101/EC.

European Union. Regulation 1008/2008/EC.

European Union. Regulations, Directives and other acts. Available online from: https://europa.eu/european-union/eu-law/legal-acts_en. [Accessed March 25, 2018].

Havel, B.F., and Mulligan, J.Q. (2012). The Triumph of Politics: Reflections on the Judgment of the Court of Justice of the European Union Validating the Inclusion of Non-EU Airlines in the Emissions Trading Scheme. Air \& Space Law, 37(1), 4.

Indonesia. Presidential Regulation No. 36 Year 2010 regarding List of Business which are Closed and Conditionally Open for Foreign Investment.

International Civil Aviation Organization. (2007). Outlook for Air Transport to the Year 2025.

International Civil Aviation Organization. (2010). Assembly Resolution A37-19.

International Civil Aviation Organization. (2013). ICAO Environmental Report 2013: Aviation and Climate Change.

International Civil Aviation Organization. (2016). Assembly Resolution A39-3.

International Civil Aviation Organization. (2016). Working Paper A39-WP/189.

International Civil Aviation Organization. (2017). Carbon Offsetting and Reduction Scheme for International Aviation (CORSIA). Available online from: https://www.icao.int/ environmental-protection/Pages/market-based-measures.aspx. [Accessed January 4, 2018].

International Civil Aviation Organization. About ICAO. Available online from: https://www.icao.int/about-icao/Pages/default.aspx. [Accessed March 25, 2018].

International Civil Aviation Organization. The History of ICAO and the Chicago Convention. Available online from: https://www.icao.int/about-icao/History/Pages/ default.aspx. [Accessed January 4, 2018].

Livemint. (2013). EU Says It Hasn't Sent Penalty Notifications to Air India, Jet. Available online from: http://www.livemint.com/Politics/ZKtKeEe01IaPpzpsp8FnGI/EU-says-ithasnt-yet-sent-penalty-notifications-to-Air-Indi.html. [Accessed January 4, 2018].

Manzini, P., and Masutti, A. (2012). The Application of the EU ETS System to the Aviation Sector: From Legal Disputes to International Retaliations?. Air E Space Law, 37(4/5), 312-313. 
Nugraha, R.A. (2015). AirAsia: Flying Cabotage Under Cloak in Indonesia and ASEAN. Jurnal Hukum \& Pembangunan, 45(2), 163-180.

Organization for Economic Co-operation and Development. (2006). Developed, Developing Countries. Available online from: http://stats.oecd.org/glossary/detail.asp? $\underline{I D=6326}$. [Accessed March 29, 2018].

Steppler, U., and Klingmüller, A. (2009). EU Emissions Trading Scheme and Aviaton: Quo Vadis?. Air E Space Law, 34(4/5), 259.

Thailand. Act Year 1954 regarding Air Navigation.

The International Bureau of the Permanent Court of Arbitration (ed.). (2002). Arbitration in Air, Space and Telecommunications Law. Den Haag: Kluwer Law International.

The Moscow Times. (2012). European Airlines Denied Overflight. Available online from: https://themoscowtimes.com/articles/european-airlines-denied-overflight-15383. [Accessed January 4, 2018].

Truxal, S. (2011). The ICAO Assembly Resolutions on International Aviation and Climate Change: An Historic Agreement, a Breakthrough Deal, and the Cancun Effect. Air E Space Law, 36(3), 219.

United Nations Climate Change. Kyoto Protocol. Available online from: http://unfccc.int/kyoto_protocol/items/2830.php . [Accessed March 26, 2018].

United Nations Conference on the Human Environment, June 1972.

United Nations Framework Convention on Climate Change, 10 December 1997.

United Nations. Vienna Convention on the Law of Treaties, 23 May 1969. 